\title{
The Inspirations of West Point School-Running Thoughts on China's Higher Education
}

\author{
Xiaowei Feng \\ Ideological and Political Department, Xi'an Peihua University, Xi'an, Shaanxi, China, 710125
}

Keywords: West Point; higher education; inspiration

\begin{abstract}
In order to promote the healthy development of China's college education in new era, this paper adopts comparative research method, takes West Point school-running thoughts as research sample, and analyzes its school-running thoughts, talent training goal, and staff construction. This paper puts forward that the innovation development of China's college education shall learn from West Point experience, and take the road of sustainable development, quality-oriented college construction with characteristics.
\end{abstract}

\section{Introduction}

The National Education Conference held on September 10, 2018, clearly defined the strategic positioning of education, and elaborated on a series of directions and measures, such as strengthening moral education and cultivating people, showing respect to teachers and attach great importance to education, and deepening reform, and further clarified the fundamental problem about the content, method and purpose of cultivating people. ${ }^{[1]}$ In order to do a good job in the education to the satisfaction of the people in new era, it is necessary to take the initiative in our own hands; however, it is also required to learn from education experience and practice of other countries. The United States West Point Military Academy has achieved brilliance with its advanced and unique school-running thoughts. Its historical formation, core content and specific practices of its school-running thoughts are valuable for research and reference. However, it is not advisable to simply copy and mechanically apply the school-running thoughts and practice of West Point. It is required to combine the reality of China's colleges and universities, grasp the fundamental, absorb the essence, truly learn from the experience, and develop a higher education with Chinese characteristics.

\section{With reference to West Point School-Running thought of “All for Students' Grown-up and Excellence”, China's College Education Should Focus on the Talent Training Goal and Take the Road of Sustainable Development.}

Focus on the mission of "strengthening moral education and cultivating people", make efforts to build the education system with the comprehensive cultivation of moral, intellectual, physical, aesthetic and labor education, and form higher-level talent cultivation system is the premise and guarantee of sustainable development of higher education. From school-running thoughts of West Point of "All for All for students' grown-up and excellence", it can be clearly seen that it is necessary to adhere to people-oriented thought, keep stable policy system of colleges and universities, and determine scientific talent cultivation objective, to guarantee benign circulation and sustainable development of higher institution construction.

\subsection{Advanced and scientific school-running concept}

Education, fundamentally, is the cause of cultivating people, with the biggest characteristics of serving the people. West Point military academy adheres to the school-running concept of "All for students' grown-up and excellence”, fully explore people's potential, fully mobilize people’s initiative, and give fully play to people's interest, so as to promote the comprehensive development of school construction. ${ }^{\text {[2] }}$ To strengthen higher education, it is necessary to adhere to be centered on people cultivation, with students as the subject; the school-running shall be talent-oriented with teachers as the subject. In order to meet this requirement, it is required to build corresponding educational concept, and do a good job in the 
top-level design of college education. First of all, to establish the concept of open education. Centered on students and learning, various means and methods of teaching and learning shall be adopted to give certain autonomous right to choose course, learning way, learning process, time and place all can be decided by students themselves. Secondly, to build up the concept of innovative education. Students shall be considered as independent individuals to be good at discovering and realizing meaningful new knowledge, new thought, and new method, to grasp basic laws hidden and to be equipped with corresponding quality and capability. Thirdly, to develop the concept of general education. The education on basic knowledge, such as human science, nature science, engineering technology, information and science technology and foreign language shall be strengthened to equip students with profound and firm basis in knowledge and capability.

\subsection{Stable and continuous institutional policy}

Stable and continuous institutional policy is the important guarantee for the stable development of college construction, and the necessary requirement for college education law. The United States West Point Military Academy, just because of the stable and continuous institutional policy, has more than 200 years of sustained development, and today's brilliant achievements. China's college education is no exception, it is necessary to maintain the stability of the institution. On the one hand, the dynamic reform, continuous improvement and tendency to be scientific and reasonable of higher education institution are the pursuit; on the other hand, it is necessary to remain the vigor of college education development, developing in relative stability and keeping stable in continuous reform. Besides, it is also required to remain the continuity of regulations and laws, which can fundamentally ensure the continuous stability of college development.

\subsection{Accurate positioning of cultivation objective}

To establish scientific talent cultivation objective is a major problem mattering what kind of talents higher institutions will cultivate. The school-running practice of West Point, takes "cultivating the leader with noble character" as the objective of talent cultivation, so that talents cultivated can meet the requirement of army and social need, to ensure the coordinated development of college construction. The task and nature of China's college education decides that it is necessary to put moral quality in the first place, keeps cultivating talents with inter-disciplinary knowledge structure and comprehensive capability as the major task, strengthens the recognition that serving society requires high-quality talents support; adheres to take the cultivation of innovative spirit and capability as fundamental requirement, and makes clear that "satisfying the society" is the basic evaluation standard of talent quality.

\section{With Reference to West Point school-running thought of "Survive on Quality", China's College Education should Meet the Requirement of Social Development and Take the Road of Quality-Oriented College Construction.}

The basic task of China's college education is to implement talent strategic project and cultivate high-quality talents who satisfy social requirement. From West Point school-running thought of "Survive on Quality", it can be seen that teaching quality is the life of colleges and universities, and plays an important role in talent cultivation. Therefore, the implementation of talent strategic project brings the opportunity for college construction, and the development of college education can also powerfully promote the implementation of talent strategic project.

\subsection{To grasp college construction as source project}

With the development of times and deepening of reform, the role and function of college education in economic social development is more and more important, which already becomes the source project of talent construction. Source project is to train high-quality talents for the society. Without high-quality talents, there is no modern construction. Thus, college education shall be put in the first place. The United States Army pays attention to investment on education, the fund for colleges and universities accounting for $6 \%$ of the total amount of military expenditure. The teaching equipment and instrument of West Point are advanced, and technical equipment is the latest in the troops. It is believed that modern war begins 
from classroom and laboratory. It may not take much time for the two armies to fight against each other on the battlefield, but the victory and defeat was decided on the battlefield of the college education before the war. ${ }^{[2]}$ In order to adapt to the requirement of social development in the future, college education shall be people-oriented; to improve the quality of talent cultivation, college education shall develop in the first place.

\subsection{To give fully play to the function of colleges and universities as main channel}

The fundamental task of college education is to train talents, which is completely consistent with the purpose of implementing talent strategic project. The advantage of colleges and universities in talent cultivation determines that they must play the role of the main channel in the talent strategic project. The US army also believes that the most fundamental function of colleges and universities is to "maintain a team of modern officers capable of leading the future war." West Point Military Academy adheres to the direction of "All for the victory of war" and insists on the training goal of "cultivating the leader with noble character", and adheres to the training model of "comprehensive development in moral, intellectual, military and physical education”, to train talents for the war and for army construction. ${ }^{[2]}$ The fact that many talents of US army are cultivated by West Point fully indicates the role of colleges and universities in military talent cultivation. As the most intensive place of knowledge, intelligence and talents in the whole society, China's colleges and universities shall become the cradle of talent cultivation, the think tank of social construction decision-making, the base of scientific research, and the center of information service. Only in this way can China's college education play a role in talent strategic project as the main channel.

\subsection{To grasp talent cultivation as systematic project}

Talent cultivation is a complex systematic project that requires the support of colleges and universities, society, and families. It needs to rely on the strength from all aspects and needs the atmosphere of working together to educate people. The US is a country that relied on national education to train military officers earlier. It has set up more than 530 reserve officers training groups in more than 500 colleges and universities across the country. They believe that West Point Military Academy is a "university of military academy" and the reserve officer training group is a "military school in university". Although the US military academies have a large amount of funding, they still attach great importance to relying on social forces to run schools, so as to improve the quality of personnel and save money. The US military troops provided a good practical guarantee for the military academy students. The internship training of the trainees was taken as an integral part of the military work, and the cultivation of talents was taken as the joint responsibility of higher institutions and the troops, forming a benign interaction between the troops and higher institutions. ${ }^{[2]}$ In accordance with the requirements of "making joint efforts to cultivate talents”, China's college education should conscientiously fulfill the respective responsibilities of higher institutions and the society in the cultivation of talents, give full play to the dual advantages of higher institutions and societies, form an atmosphere of higher institutions and the society making joint efforts to educate people, and strive to cultivate high-quality innovative talents to better serve the society.

\section{With Reference to West Point School-running thought of "Develop on Characteristics", China's College Education Should be based on Its Construction Reality and Take the Road of College Construction with Characteristics.}

Education is the foundation of national development in the long run. Building a country with strong education is the basic project of the great rejuvenation of the Chinese nation. Training talents with both ability and political integrity is the historical mission of higher education. This determines that college education in China shall not only adapt to the needs of mission, but also highlight their own characteristics. West Point Military Academy covers an area of 96,000 mu, but it has only 4,000 students. West Point has world-class teaching facilities and faculty, but it only has a bachelor's degree education, but it also has become a special institution with world influence. ${ }^{[3]}$ From West Point school-running thought of "Develop on Characteristics", it can be seen that college education cannot be greedy and 
demanding, and it must do something and refrain from doing something, whereas, the key is to have its own characteristics.

\subsection{To focus on the construction of key colleges and universities}

The US military has 113 colleges and universities, and only four institutions are key construction projects, namely the Army Military Academy (West Point Military Academy), the Naval Academy, the Air Force Officer School, and the Coast Guard School. These four institutions implement undergraduate education at the same level of culture as local universities, while other institutions implement an in-service education system that separates basic education from professional education, thus achieving the key guarantee for key institutions in teachers, capital, and manpower. ${ }^{[2]}$ It is required to follow the principle of “emphasizing key points, taking into account general points and developing harmoniously", and also concentrate on the quality of colleges and universities, and more specialized schools that are closely integrated with social needs. At present, "returning undergraduate education" has become the consensus and trend of international higher education. College education must take root in China, integrate with China and foreign countries, based on the times and facing the future, and develop world-level modern higher education with Chinese characteristics.

\subsection{To focus on the construction of staff}

Building a first-class university is inseparable from two conditions. One is to have first-class leaders and principals, and the other is to have first-class masters and experts, namely teachers and teaching management cadres. The past presidents of West Point have the qualities of experts and scholars, such as the father of West Point, Sayer, MacArthur, etc. They not only have high academic attainments, but also understand higher institutions and understand the troops. In China's college education, it is also necessary to pay attention to experts and scholars, and highlight the construction of teaching staff and teaching management cadres. In particular, it is required to focus on capacity construction, focus on technical talents, and work hard on the four aspects of talent introduction, training, use, and care. It is necessary to strive to build a professional leading group with strong politics which knows education and management, a team of teachers with high academic level, good teaching effect, strong scientific research ability, and high academic level, standing at the forefront of discipline development, and a team of teaching management cadres who are dedicated and have a complex knowledge structure.

\subsection{To focus on the construction of teaching quality}

Teaching quality is the life of colleges and universities, and the basis of their existence and development. In order to ensure the quality of teaching, West Point Military Academy adopts small class teaching, advocates independent learning, and uses advanced teaching methods to cultivate students' innovative ability and implement elimination in the whole process. They believe that there is no quality without elimination. ${ }^{[4]}$ In order to ensure the quality of teaching in China's colleges and universities, it is necessary to re-integrate the existing professional structure, break the professional boundaries, and implement the optimizing configuration of educational resources in accordance with the requirements of "optimizing the structure, broadening the channel, selecting the support, focusing on the key construction, forming the characteristics, and improving the level”, and strive to cultivate a large number of high-quality professionals who are qualified, innovative, and brave in practice, providing a solid talent foundation for national rejuvenation. It is required to construct the teaching system with cooperation of compulsory courses, elective courses, self-study courses, and integration of natural sciences, humanities and other multidisciplinary content, popularize heuristic teaching, promote democratic teaching, adhere to open teaching, pay attention to research-based teaching, and continuously carry out innovations in teaching methods, learning methods and test methods, in accordance with the requirements of "establishing a scientific, comprehensive and advanced content system tracking the frontiers of the development of science and technology, and adapting to the requirements of social development". It is necessary to adhere to the principle of people-oriented, principle of temper justice with mercy, and integrate teaching, learning, management, protection, and research into one, and pay close attention to the teaching style, study style, test style, and school spirit, and create a good management educational environment, in accordance with the requirement of "law-based strictly school-running". It is urgent to 
strictly implement the promotion and repetition, encourage outstanding students, promote backward students, and eliminate unqualified students, in accordance with the provision of "School Enrollment Management System”.

\section{Conclusion}

In conclusion, the research explores the inspirations of school-running thoughts of West Point Military Academy on Chinese college education. Briefly, it is necessary to do a good job in "three projects", including source project to firmly establishes the status and role of college education; talent cultivation systematic project to keep making joint efforts to education people by college and the society; modern teaching project to continuously improve the quality of talent cultivation, and "five good", including good school-running concept, good policy and regulations, good system, institution, mechanism and staff, good scale, structure, quality and benefits, and good leaders, guidance and supervisors.

\section{References}

[1]. Xi Jinping. Speech on National Education Conference [N]. Guangming Daily, 2018-09-11 (1).

[2]. Gao Feng, Guo Xingwei, Zhu Hai. School-running Thoughts of West Point Military Academy [J]. Political Workers, 2011, (3).

[3]. Xiong Wei. The Construction and Inspirations of Curriculum in West Point Military Academy [J]. Management Observer, 2013, (2).

[4]. Hong Chengwen. International Experience of World First-class Discipline Development [J]. China Higher Education, 2018, (5). 